1741. It was then confined to two islands (Behring's Island and Copper Island). In forty years (1780) it was believed to have been entirely extirpated. It was a toothless herbivore, living along the shore in shallow water, and was easily taken, being without fear of man. Its flesh was good, and it weighed often 3 or 4 tons.

The Author then described some of the leading points in the anatomy of Rhytina, and indicated some of the characters by which the order is distinguished. He referred to the present wide distribution of the Sirenia:-Manatus with three species, namely, $M$. latirostris, occupying the shores of Florida and the West Indies; $M$. americanus, the coasts of Brazil and the great rivers Amazon and Orinoco; $M$. senegalensis, the west coast of Africa and the rivers Senegal, Congo, \&c.

Halicore with three species, namely, H. tabernaculi, the Red Sea and east coast of Africa; $H$. dugong, Bay of Bengal and East Indies; H. australis, North and East Australia.

The fossil forms number thirteen genera and twenty-nine species, all limited to England, Holland, Belgium, France, Germany, Austria, Italy, Malta, and Egypt, and to the United States and Jamaica.

The Author gave some details as to the dentition of fossil species, of which Halitherium and Prorastomus are the two most remarkable types.

Lastly, with regard to the geographical area occupied at the present day by the Sirenia, the Author pointed out that two lines drawn $30^{\circ} \mathrm{N}$. and $30^{\circ}$ South of the equator, will embrace all the species now found living. Another line drawn at $60^{\circ} \mathrm{N}$. will show between $30^{\circ}$ and $60^{\circ} \mathrm{N}$. the area once occupied by the twenty-nine fossil species.

He looked upon Rhytina as a last surviving species of the old Tertiary group of Sirenians, and its position as marking an "outlier" of the group, now swept away.

The greater northern extension of the group seems good evidence of the once warmer climate enjoyed by Europe, Asia, and America in the Tertiary epoch.

\title{
MISCELLANEOUS.
}

Preliminary Notes on the Echinoderms of Beaufort. By Henry F. Nachtrieb.

RECENT work on the morphology and embryology of invertebrates and the speculations on the phylogeny and relationships of the various classes of animals now claiming the morphologist's consideration make a coherent history of the evolution of the Echinoderms very desirable, especially as no satisfactory explanation (so far as I know) of this interesting class of Invertebrates has ever been given. From what has been done it is evident that before we can Ann.\& Mag. N. Hist. Ser. 5. Vol.xv. 
safely speculate on the relationships of Echinoderms to Nemerteans \&c., we must get a clear understanding of the evolution of the class itself. Towards this understanding no two investigators have contributed more than Johannes Müller in his memoirs, and Ludwig in his classical 'Beiträge.' But much remains yet to be done, and it was with a view to add something to our knowledge of this group that I began my work, at the suggestion of Dr. Brooks, at Beaufort, early last June. These Notes are rather an earnest of what is to be than a synopsis of what has been done.

The Echinoderms of Beaufort represent all the orders except the Crinoids, and with one or two exceptions are abundant, easily obtained, and in their variety offer excellent material for comparative work and for the solution of puzzling and important questions.

The starfish are represented by Asterias Forbesii, Luidia clathrata, Astropecten articulatus, and an undetermined species, of which I found only one specimen. This specimen was closely related to Luidia and Astropecten, and may prove to be a cross between the two-which surmise suggests some experiments in a field which certainly is promising. Of the Ophiurids great numbers of Ophiothrix angulata are found in the cavities of the sponges so abundant in certain parts of the harbour; some Ophiophragma Wurdemanii, Lyman, are found in the sand on Shark Shoals. Great numbers of Ophiura olivacea are found among the eel-grass in various parts of the harbour, and one undetermined species was dredged in deep water. The Echinoids are represented by thousands of the $\mathrm{Cly}-$ peastroid, Mellita petapora, Lütk., commonly known as the sanddollar, great numbers of Sea-Urchins, Arbacia and Strongylocentrotus, and by one Spatangoid, Moira atropos, which is common in the sand on Shark Shoals. The Holothuriaus are represented by Synapta and several undetermined species.

When I arrived at Beaufort last June, the sand-dollar was spawning, and I accordingly began my work on it. The eggs, when laid, are surrounded by a gelatinous membrane, in which are lodged numbers of large purplish-red pigment-granules, which vary in size and shape, and are always more or less angular. Fertilization takes place through this membrane. In no case could I see anything like a polar globule. The first two planes of segmentation (meridional) and the third, which is equatorial, divide the egg into eight blastomeres of equal size--occasionally the four at one pole are a trifle larger than the four at the opposite pole. After eight blastomeres are formed irregularities in segmentation begin, but as I did not pay special attention to segmentation I shall not attempt a description of the process.

After the blastosphere is formed each cell acquires a cilium; the larva then begins to rotate within the membrane, and at length wears through one portion of it and then escapes into the water. It is generally stated that the blastosphere and gastrula of Echinoderms are uniformly ciliated. This, I am prepared to say, is not altogether true-at least it is not true for all the forms studied at Beaufort.

At the pole opposite to where the blastopore is formed is a small circular area in which the cilia are longer, stronger, and less active 
than those at any other point of the larva. When the gastrula is swimming these long cilia are directed forwards, now and then sway to and fro slightly, but never aid in propelling or turning the larva, apparently being inactive except that occasionally they seem to act as sensory cilia. In some few cases this area with the long cilia was somewhat thicker than the neighbouring ectoderm. This thickening of the ectoderm and greater length of cilia over this thickened area was very marked in many Strongylocentrotus-gastrulæ, and it was always easily recognizable in Ophiothrix, and was well marked in Moira. Nothing of the kind was observed in the few starfish-gastrulæ I was able to get. That we have here to do with a differentiation peculiar to this part of the larva only, and that it is to some extent comparable to the region of the præoral tuft of cilia of other larvæ, is shown by the fact that it is marked some time before the larva escapes from the membrane, and that it exists long before there is the slightest indication of the posterior and the unmistakable anterior ridge of the ciliated band of the future Pluteus. And that it is not an optical delusion due to a difference in the rapidity and manner of vibration of the cilia in different parts of the larva is proven by specimens killed on the slide with osmic acid or other hardening fluid. How much importance can be attached to this fact will be discussed in a later paper. In passing I would, however, here point out that it is possible to explain the præoral band of cilia of Bipinnaria as a modified form of this group of long cilia, and that in those forms where we have but one band of cilia, these long cilia of the gastrula have merged into the anterior ridge of cilia, which then united with the postoral ring. The body-cavity and water-vascular system of Mellita is derived from a two-horned diverticulum of the enteron, just as in Strongylocentrotus. In Moira the process of segmentation, which is regular only up to eight blastomeres, leads to a blastosphere, this to a bilaterally symmetrical gastrula, which gradually develops into a nine-armed Pluteus, the posterior unpaired arm arising soon after the two ventral ones. No polar globules were seen. The bodycavity and water-vascular system arise as they do in Mellita. A phenomenon observed one day while fertilizing some immature eggs of Moirc deserves mention here. The immature eggs have a clear distinctly visible nucleus and a number of clear spaces of varying sizes. Some of these eggs were mixed with active spermatozoa, and in a few moments after the spermatozoa had been added quite a number of pseudopodia were thrust through the egg-membrane, which, after having felt about a short time, again slowly withdrew themselves. The eggs did not undergo segmentation, and some hours later disintegrated. Want of time did not permit me to experiment in this direction.

The small opaque eggs of Ophiothrix always threw off two polar globules after being mixed with the male fluid. The first two planes of segmentation are meridional, the third is equatorial. The eight blastomeres are equal in size. As in the cases mentioned above, so here segmentation begins to be irregular. In the cases that came under my observation the segmentation of Ophiophragma was regular till four blastomeres had been formed. These eggs 
were obtained but a few days before my departure, and owing to circumstances I could not follow the segmentation any further at the time, and then southerly winds and high water cut off my work, so that I was able to get only the latter half of the development of the eggs I had obtained one afternoon from some of the Ophiurids I had in an aquarium. The eggs were laid in the afternoon about four o'clock, and early next morning the larva already had passed the important stages. One interesting thing was noticed in the segmentation so far as observed. The first two blastomeres, before completely separating, were connected at their middle points by a spindle-shaped body, which was finally constricted off, the two blastomeres having widely separated from each other, then gradually came towards the surface, became spherical, and looked very like a polar globule. The blastomeres rounded out, and again approached each other. Each next divided into two, a body similar to the one mentioned above being given off between each pair of blastomeres, which again widely separated from each other, rounded up, and then approached each other again. At this stage I was obliged to leave. Whether what I saw was the result of a pathological condition or not I cannot say. The larvæ I found in my aquaria the next morning were pyramidal bodies, somewhat flattened, drawn-out gastrula-shaped bodies, of which the anterior bluntly-pointed half was transparent, consisting of a single layer of ciliated ectoderm-cells around a eavity in which were branched mesoderm-cells, and of which the posterior broad end with the blastopore was dark, quite opaque, and already had established in it the enteron with its diverticula. The Ophiurid developed entirely in this posterior half of the larva. The anterior transparent half was gradually resorbed, and, so far as observed, no special invagination for the mouth obtained. On the starfish observed I have nothing new to add at present.

A few words on the phylogeny of the Echinoderms. If we compare the origin of the body-cavity and water-vascular system in the different classes we see that in the Holothurians we have one median pouch given off from the enteron, and that it, by division, gives rise to the body-cavity and water-system. In the Echinoids there is a two-horned pouch given off. In the starfish there are two separate lateral pouches given off, of which the left gives rise anteriorly to the water-system, and the right and the posterior part of the left become the body-cavity. In Ophiurids, so far as known, there are two separate pouches, both of which divide, the anterior part of the left becoming the water-system, the anterior of the right atrophying, and the posterior parts of the right and left becoming the bodycavity. In the Crinoids there are first given off two separate pouches, which become the body-cavity, and then a single one, that becomes the water-system. Assuming that the story of the Ophiurids and Crinoids is correct, we have here a rising scale, in which the Holothurians occupy the lowest, the starfish the middle, and the Crinoids the highest position. In favour of this there are some anatomical facts. The objections of palæontology are not very difficult to answer. In assuming the Holothurians as the primitive forms it is not necessarily implied that the line of development is a 
straight one, as it is represented above. It is quite probable that the line began to break with the appearance of the starfish.-Johns Hopkins University Circulars, March 1885, p. 67.

\section{A new Freshwater Sponge from Nova Scotia.}

Mr. E. Potts described a form recently identified by him as follows :-

\section{Heteromeyenia pictouensis, n. sp.}

Sponge light green, even when dry, massive, incrusting; texture very compact; spicules non-fasciculated, persistent; surface mostly smooth.

Gemmules very scarce, spherical, crust thick.

Skeleton-spicules cylindrical, short, robust, rounded or abruptly terminated; entirely spined, spines conical at the centre of the spicule, elsewhere generally curving forward, or towards each extremity. Rounded terminations of spicules covered with short spines, though frequently a single large spine or acute termination is seen at one or both extremities.

Dermal spicules absent or undiscovered.

Birotulates of the longer class surrounding the gemmules, rather numerous, one half longer than the others; shafts conspicuously fusiform or largest at the centre, where are frequently found one or more long spines. Their rotules consist of from three to six irregularly placed rays, recurved at the extremities.

Birotulates of the shorter class abundant and compactly placed around the gemmule; shafts mostly smooth, though sometimes bearing a single spine, irregularly cylindrical, but rapidly widening to support the rotules, which are large, umbonate, nearly flat, and finely lacinulate at their margins; occasionally bearing spines.

Measurements. Skeleton-spicules 0.0075 inch long by 0.00075 inch thick; length of long birotulates 0.0021 inch, of short birotulates 0.0012 inch; diameter of disk of latter 0.0009 inch.

Habitat. On submerged wood \&c.

Locality. Collected only by or for Mr. A. H. McKay, B.A., B.S., of Pictou, Nova Scotia, from several lakes upon the watershed of that region.

This beautiful and interesting sponge was first discovered by Mr. McKay during the summer of 1884. At that time its novelty, as indicated by its unusual!y robust entirely spined skeleton-spicules, was easily recognized; but the absence of gemmules at that season precluded the determination of its generic relations, and it has continued unnamed. During the last week of December, however, a further search was rewarded by the finding of other "specimens upon sticks pulled up through a break made in the ice," and amongst these a few, and but a few, gemmulæ have now been discovered.

These suffice to place it clearly within the genus Heteromeyenia, near $H$. Ryderii, while the peculiarities of its birotulates distinguish it from that or any other species. 


\section{$2 \mathrm{BHL}$ Biodiversity Heritage Library}

Nachtrieb, Henry F. 1885. "Preliminary notes on the Echinoderms of Beaufort." The Annals and magazine of natural history; zoology, botany, and geology 15, 421-425. https://doi.org/10.1080/00222938509459358.

View This Item Online: https://www.biodiversitylibrary.org/item/53785

DOI: https://doi.org/10.1080/00222938509459358

Permalink: https://www.biodiversitylibrary.org/partpdf/53226

\section{Holding Institution}

Smithsonian Libraries

\section{Sponsored by}

Smithsonian

\section{Copyright \& Reuse}

Copyright Status: Public domain. The BHL considers that this work is no longer under copyright protection.

This document was created from content at the Biodiversity Heritage Library, the world's largest open access digital library for biodiversity literature and archives. Visit BHL at https://www.biodiversitylibrary.org. 